\title{
Fluvial deposits of the Diamante Formation as a record of the Late Cretaceous tectonic activity in the Southern Central Andes, Mendoza, Argentina
}

\author{
*Ricardo Gómez ${ }^{1,2,3}$, Maisa Tunik ${ }^{1,2}$ y Silvio Casadío ${ }^{1,2}$ \\ 1 Universidad Nacional de Río Negro. Instituto de Investigación en Paleobiología y Geología, Av. Roca 1242, General Roca, Río Negro, Argentina. \\ rgomez@unrn.edu.ar; mtunik@unrn.edu.ar; scasadio@unrn.edu.ar. \\ 2 Consejo Nacional de Investigaciones Cientificas y Técnicas (CONICET), Instituto de Investigación en Paleobiología y Geología, \\ Av. Roca 1242, General Roca, Río Negro, Argentina. \\ ${ }^{3}$ Museo de Historia Natural de San Rafael, Av. Balloffet $S / N^{\circ}$ frente al Parque Mariano Moreno, San Rafael, Mendoza, Argentina. \\ * Corresponding author: rgomez@unrn.edu.ar
}

\begin{abstract}
The Upper Cretaceous nonmarine deposits of the Neuquén Basin have an important regional exposure. These deposits are included in the Neuquén Group, a well-studied unit in both the south and central part of the basin. However, the northernmost exposed between the Laguna del Diamante and the Atuel River-assigned to the Diamante Formation-have not been studied in detail. In the studied area, the Diamante Formation corresponds to a braided fluvial system with moderate sinuosity evolving through time towards an anastomosing fluvial system. Petrographic analyses indicate that sandstones belong to feldspatic litharenites and litharenites, while the source area indicates provenance from both a recycled orogen and a transitional arc. The latter could be linked to the exhumation of the Andean orogen located to the west and to the input from the north-eastern border of the Neuquén Basin, represented by the rocks currently exposed in the San Rafael Block. On a macroscopic scale, the presence of calcareous lithic fragments in the mid and upper part of the surveyed stratigraphic section, strongly suggest an input from the west. This indicates an important change in the polarity of the basin and the presence of a deformation front located to the west of the study area in accordance to previous proposals in equivalent deposits to the south of study area.
\end{abstract}

Key words: Neuquén Basin, Diamante Formation, Fluvial systems, Detrital modes, Andean orogen.

RESUMEN. Depósitos fluviales como un registro de la actividad tectónica del Cretácico tardío en el sur de los Andes centrales, Argentina. Los depósitos continentales del Cretácico Superior de la cuenca Neuquina tienen una importante exposición regional. Estos depósitos se incluyen en el Grupo Neuquén, unidad muy estudiada tanto en el sur como en el centro de la cuenca. Sin embargo, los afloramientos más septentrionales que se encuentran entre la laguna del Diamante y el río Atuel, asignados a la Formación Diamante, no han sido estudiados en detalle. La Formación Diamante, en el área estudiada, corresponde a depósitos de un sistema fluvial entrelazado de sinuosidad moderada que evoluciona a través del tiempo a un sistema fluvial anastomosado. El análisis petrográfico indica que las areniscas corresponden a litoarenitas feldespáticas y litoarenitas, mientras que el área de aporte es compatible con una procedencia desde un orogeno reciclado y un arco magmático transicional. Esto último podría estar asociado tanto a la exhumación del orógeno Andino situado al oeste, como así también al aporte desde el borde nororiental de la cuenca Neuquina, representado por las rocas actualmente expuestas en el Bloque San Rafael. En una escala macroscópica, la presencia de fragmentos líticos calcáreos en la parte media y superior de la sección estratigráfica relevada, confirma el aporte desde el oeste. Esto indica un cambio importante en la polaridad de la cuenca y la presencia de un frente de deformación ubicado al oeste de la zona de estudio, de acuerdo con las propuestas anteriores en depósitos equivalentes ubicados al sur del área estudiada. 


\section{Introduction}

The Upper Cretaceous nonmarine deposits in the central-western area of Argentina are widely exposed in the provinces of San Juan, Mendoza, Neuquén, and Río Negro, reaching a thickness of 1,600 $\mathrm{m}$ at some localities (Orts et al., 2012). These deposits are composed by red nonmarine facies, rich in vertebrate fossils, which were deposited during the CenomanianCampanian, reflecting the development of large fluvial systems with intercalations of aeolian systems and shallow lakes (Garrido, 2010 and references therein). In the central and southern areas of the Neuquén Basin, lithofacies, facies association, petrography and $\mathrm{U}-\mathrm{Pb}$ ages from detrital zircons, indicate that the sedimentary rocks included in the Upper Cretaceous Neuquén Group would have been linked to the early uplift of the Andean orogen (Fig. 1) (Tunik et al., 2010; Di Giulio et al., 2012, 2016; Balgord and Carrapa, 2016; Fennell et al., 2017a). Before deposition of the Neuquén Group, the positive areas were located towards the east and behaved as source areas for fluvial systems and perennial lakes. Those perennial lakes with variable salinity were affected by hyperpycnal discharges and are represented by the sedimentary rocks grouped within the Rayoso Formation (Zavala et al., 2001; Ponce et al., 2002). The northern outcrops of the Neuquén Group located between Laguna del Diamante and Atuel River (Figs. 1 and 2), receive the name of Diamante Formation (discussed below). These deposits have not been studied in detail and are relevant for the geological background used by oil companies such as YPF (Cruz, 1993). Sruoga (2000) studied the regional geology of the Maipo Volcano area, while Broens and Pereira (2005) focused on the structural study of the area. The studied area is located in the central-western sector of Mendoza province (Fig. 2), approximately 120 $\mathrm{km}$ west from the city of San Rafael and $13 \mathrm{~km}$ from the town of Las Aucas, in the Vega Grande oil field. The results of facies analysis and the petrographic characterization of sandstone facies were carried out to identify the provenance areas and attempt a paleoenvironmental interpretation of the Diamante Formation.

\section{Geological setting}

The Neuquén Basin is located on the eastern side of the Andes in Argentina (32-40 $\mathrm{S}$ ) and contains a thick rock succession recording the interplay between tectonics, sea level and volcanic activity controlling the development of marine versus nonmarine conditions (Howell et al., 2005). It is bounded to the northeast by the San Rafael Block and to the southeast by the North Patagonian Massif, while its western margin corresponds to the Andean volcanic arc (Fig. 1). The basin presents two distinct sectors: north of $\sim 35^{\circ} \mathrm{S}$, it comprises a narrow north-south trough ( $90 \mathrm{~km}$ wide), while south of this latitude it spreads eastwards in the Neuquén Embayment (Bracaccini, 1970), where it reaches a width of $300 \mathrm{~km}$. The history of the basin reflects the tectonic evolution of the Andes at these latitudes. It began with Triassic extensional processes in a retroarc environment followed by thermal subsidence events and local tectonic inversion events during the JurassicCretaceous interval (Vergani et al., 1995; Howell et al., 2005; Silvestro and Zubiri, 2008; Armas and Sánchez, 2013 among others). Beginning in the Late Cretaceous, and due to the initial Andean uplift, it underwent the typical evolution of a foreland basin (Ramos, 1999; Tunik et al., 2010).

The basement of the basin is known as the Choiyoi Group, a Permian-Triassic rhyolitic-dacitic rock sequence interbedded with clastic successions. This unit represents the transition from a magmatic arc setting towards an extensional within-plate regime along the southwestern Gondwana margin (Llambías et al., 2003; Martínez and Giambiagi, 2010; Fennell et al., 2017a). The infill of the basin started in the Late Triassic-Lower Jurassic with the development of isolated hemigrabens controlled by normal faults. Synrift deposits consist of volcanic, volcaniclastic and sedimentary rock successions deposited in a series of isolated depocenters (Legarreta and Gulisano, 1989; Cristallini et al., 2009; Giambiagi et al., 2009). With the connection of these isolated depocenters, the Early Jurassic records the first marine transgression from the Pacific. The full cycle is represented in the basin by the intercalation of marine sandstones, shales and evaporites (Gulisano and Gutiérrez Pleimling, 1994). A second transgressive-regressive cycle took place in the Late Jurassic-Early Cretaceous and is represented by sedimentary rock sequences included in the Mendoza and Bajada del Agrio Groups. The Titho-Neocomian Mendoza Group includes different units composed by marine organic black shales rich in organic matter, thinly laminated limestones and sandstones, grading-up and interfingering with 


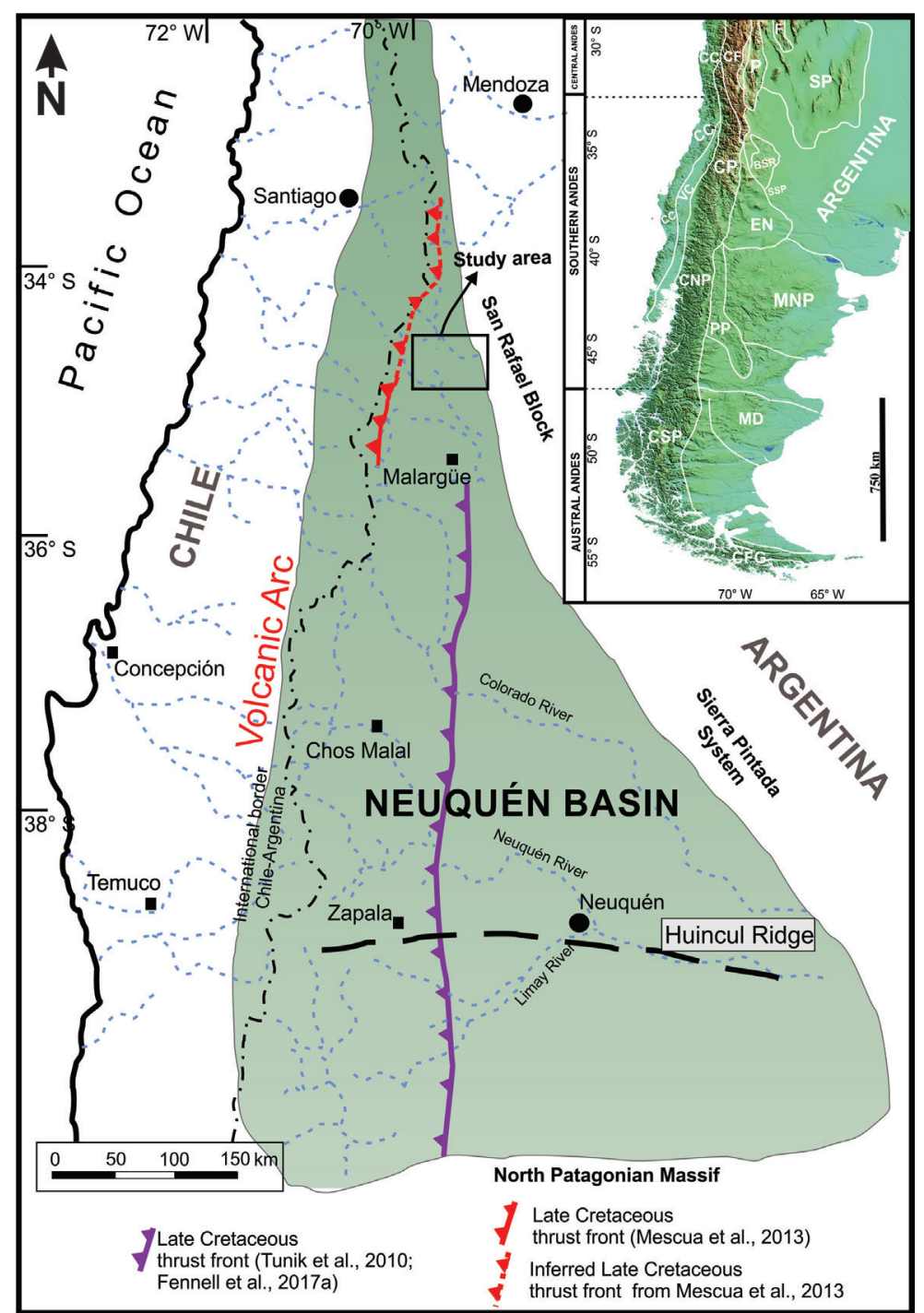

FIG. 1. Map showing the location of the Neuquén Basin and the study area (modified from Tunik et al., 2010; Mescua et al., 2013; Folguera et al., 2015; Balgord and Carrapa, 2016; Fennell et al., 2017a, b). Up to the right, main morphostructural provinces in which the Southern Andes are divided. CC: Cordillera de la Costa; CF: Cordillera Frontal; P: Precordillera; F: Sistema de Famatina; SP: Sierras Pampeanas; VC: Valle Central; CP: Cordillera Principal; BSR: Bloque San Rafael; EN: Engolfamiento Neuquino; CNP: Cordillera Norpatagónica; PP: Precordillera Patagónica; MNP: Macizo Norpatagónico; MD: Macizo del Deseado; CSP: Cordillera Surpatagónica; CFG: Cordillera Fueguina; SSP: Sistema de Sierra Pintada (Mpodozis and Ramos, 1989; Tassara and Yáñez, 2003; Folguera et al., 2015).

nonmarine redbeds and evaporites of the Bajada del Agrio Group (Tunik et al., 2010 and references therein). The Bajada del Agrio Group (Huitrín and Rayoso formations), marks the disconnection of the Neuquén Basin from the Pacific Ocean and the beginning of the continentalization of the basin (Leanza, 2003 among others). During the Late Cretaceous, the Neuquén Basin evolved into a foreland stage, reflected by the beginning of a new sedimentation cycle represented by sedimentary rocks of the Neuquén Group. The inception of a compressional regime in Late Cretaceous times, coincident with a major tectonic plate reorganization, controlled the Late Cretaceous to Cenozoic paleogeography (Somoza and 


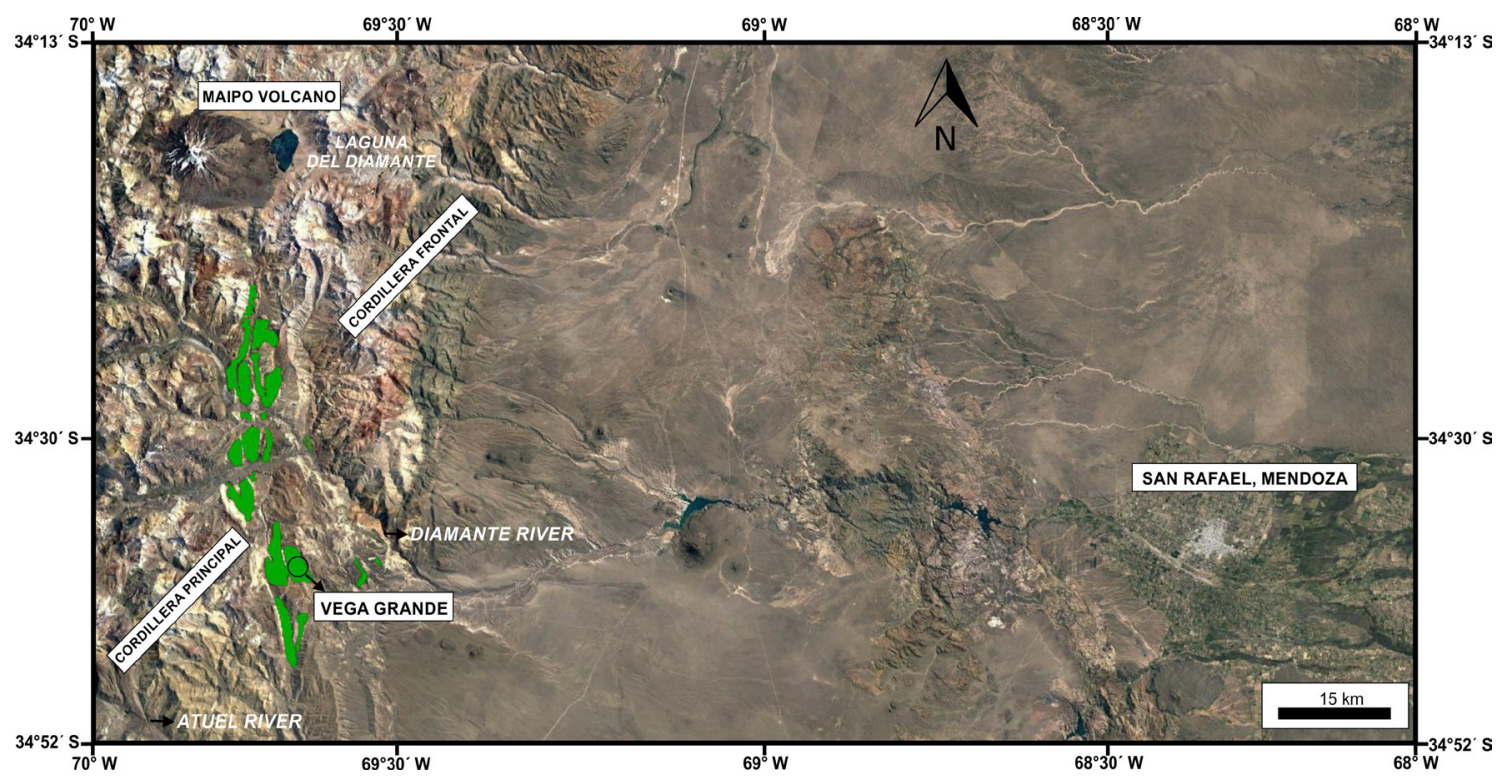

FIG. 2. Detail of the location with the main morpho-structural units, rivers and the city of San Rafael to the right of the map. In green, outcrops of the Diamante Formation between Atuel river and the Laguna del Diamante, Mendoza, Argentina (Satellite image taken from free software Google Earth Pro).

Zaffarana, 2008; Tunik et al., 2010; Orts et al., 2012). A new transgression took place from latest Cretaceous to Paleocene times, this time from the Atlantic Ocean, which is represented by the sedimentary rocks of the Malargüe Group (Aguirre Urreta et al., 2011). The foreland basin stage was interrupted between late Oligocene and early Miocene times, but resumed in the middle Miocene, when the last major contractional stage became responsible for the final shaping of the Southern Central Andes at these latitudes (Fennell et al., 2017a and references therein).

\subsection{Stratigraphy of the Late Cretaceous foreland stage}

In the central and northern area of the Neuquén Basin, the Upper Cretaceous nonmarine deposits are included in the Neuquén Group, while in northern Mendoza and San Juan provinces they are included in the Diamante Formation. The Neuquén Group contains the syn-orogenic deposits within the early Andean foreland basin and is subdivided into three subgroups (Río Limay, Río Neuquén, the Río Colorado) and seven formations: Candeleros, Huincul and Cerro Lisandro formations in the Río Limay Subgroup; Portezuelo and Plottier formations in the Río Neuquén Subgroup; Bajo de la Carpa and Anacleto formations in the Río Colorado Subgroup (Cazau and Uliana, 1973; Uliana et al., 1975; Ramos, 1981; Garrido, 2010). A nonmarine environment is interpreted for the Neuquén Group, including braided and meandering fluvial systems, aeolian and lacustrine environments (Garrido, 2010; Sánchez and Asurmendi, 2016; Asurmendi et al., 2017). This sedimentary succession is interrupted by the unconformably overlying Maastrichtian-Danian marine facies of the Malargüe Group (AguirreUrreta et al., 2008 and references therein). The unconformity at the bottom of the Neuquén Group is a basin scale unconformity observed along the whole orogenic front (Legarreta and Gulisano, 1989; Leanza, 2003, 2009; Mosquera and Ramos, 2006, Tunik et al., 2010); however, it is not visible in the studied area because the contact with the underlying Rayoso Formation is transitional (Lothari et al., 2018). The only radiometric age reported for the Neuquén Group yielded an age of $88 \pm 3.9$ Ma based on a fission-track analysis made on a tuff at the base of the Huincul Formation in the Cerro Policía area, located $600 \mathrm{~km}$ to the south of the studied area (Corbella et al., 2004). On the other hand, based 
on the youngest detrital zircons, the maximum sedimentation age of the Candeleros Formation is ca. $100 \mathrm{Ma}$ in southern Mendoza Province (Tunik et al., 2010; Di Giulio et al., 2012; Fennell et al., 2017a; Balgord and Carrapa, 2016).

Regarding nomenclature, the choice between Diamante Formation and Neuquén Group has been a stratigraphic controversy since the pioneer studies carried out by Groeber (1946). This discrepancy was generated by the different background and elements that were taken into account to correlate these units at a regional-level, given the absence of guide levels and fossil content. Some authors prefer to use Neuquén Group based on the stratigraphic similarities (Legarreta and Gulisano, 1989; Cruz, 1993; Fennell et al., 2017a; Horton et al., 2016). However, it is not always possible to detect the same facies arrangement, probably due to changes in the sedimentation controls, among other factors. Nowadays, the age of detrital zircons is an important tool used to correlate between the nonmarine deposits outcropping in Mendoza province and the Neuquén Group defined further south (Fennell et al., $2017 b$ ). Taking into account all of the above, in this contribution we consider it is more appropriate to use Diamante Formation when referring to the studied rocks. A future challenges is to obtain more correlation elements for the Diamante Formation located between the Laguna del Diamante and the Atuel River, with respect to the Upper Cretaceous sedimentary rock located to the south and north of the study area.

\section{Methodology}

This study reports new sedimentological and petrographic data from the Diamante Formation. These are used to identify depositional environments, establish stratigraphic correlations, to analyse textural and compositional features on sandstones and characterize the provenance based on clast-counting.

The stratigraphic analysis of the non-marine Upper Cretaceous succession was based on the survey of the stratigraphic section at a metric scale in Vega Grande area. Fieldwork included a detailed description of outcrops and measurements of Vega Grande stratigraphic section. Characterization of sedimentary facies was based on lithology, sedimentary structures (types, dimensions and orientation in case of having directional character) and internal organization. The codes system to denominate those sedimentary facies was based on Miall (1996) with slight modifications (Table 1).

On the other hand, a systematic sampling of sandstones was carried out based on a detailed stratigraphic section $\left(34^{\circ} 40^{\prime} 15.68^{\prime \prime} \mathrm{S} / 69^{\circ} 40^{\prime} 4.27^{\prime \prime} \mathrm{W}\right)$. These were later observed under a magnifying glass for a complete macroscopic description. Seventeen standard $30 \mu$ thin sections were analyzed, impregnated with blue epoxy resin in order to highlight the porosity, stained with alizarin red to distinguish dolomite and calcite and also with potassium ferricyanide to distinguish ferroan and non-ferroan calcite. After analyzing the section, 10 thin sections were selected based on their degree of alteration for the study of detrital modes and provenance (Table 2). The sandstones were classified following Folk et al. (1970) and the Gazzi-Dickinson method was used for the provenance analyses. All data was later plotted in the discrimination provenance diagrams of Dickinson et al. (1983).

\section{Results}

\subsection{Sedimentological analysis}

In the area of Vega Grande, the Diamante Formation outcrops with a thickness of $377 \mathrm{~m}$. Its base is covered and towards the top a transitional passage to shallow marine deposits of the Saldeño Formation is recorded (Tunik, 2001). In this area, the unit is divided into two upward-fining and thinning rock sequences, composed by clastic deposits in which conglomeratic, sandy and mudstone facies were identified (Fig. 3).

Nine facies were established (Table 1, Gómez et al., 2016a, b). Conglomeratic facies of variable lateral extension (from 1 to $14 \mathrm{~m}$ ) and thickness (up to $5 \mathrm{~m}$ ) present lenticular and chaotic geometries. Clast-supported orthoconglomerates (Gcm, Gct) are the most abundant facies while matrix-supported orthoconglomerates $(\mathrm{Gmm})$ are present in a lower proportion. They crop out as continuous depositional cycles that begin with coarse-conglomeratic, followed by coarse-sandstone facies and finish with medium to fine sandstone facies (Sp, Sm) with bioturbation ( $\mathrm{Sm}$ ). The sandstone facies not only appear associated with conglomeratic facies, but also appear showing both the ribbon and sheet geometries as individual bodies ( $\mathrm{Sp}, \mathrm{Sm}, \mathrm{Sh}$ ). On the other hand, mudstone facies are represented by tabular and sheet geometries, often semi-covered and with an 
TABLE 1. DESCRIPTIONS AND INTERPRETATIONS OF FACIES ORDERED BY GRAIN SIZE AND TYPE OF SEDIMENTARY STRUCTURES. BASED ON MIALL (2014) AND REFERENCES THEREIN.

\begin{tabular}{|c|c|c|c|c|c|}
\hline Facies code & Lithology & Sedimentary structures & Geometry & Interpretation & Observations \\
\hline Gcm & $\begin{array}{l}\text { Clast-supported } \\
\text { conglomerate }\end{array}$ & Massive & Lenticular- Diffuse & Hyperconcentrated flow-Sediment gravity flows & $\begin{array}{l}\text { Carbonates and volcanic rock fragments, poorly } \\
\text { to well sorted, slight imbrication }\end{array}$ \\
\hline Get & $\begin{array}{l}\text { Clast-supported } \\
\text { conglomerate }\end{array}$ & $\begin{array}{l}\text { Tangential and festoon } \\
\text { cross-bedding }\end{array}$ & Lenticular-diffuse-on wedge & $\begin{array}{l}\text { Unidirectional migration of subaqueous three- } \\
\text { dimensional dunes }\end{array}$ & $\begin{array}{l}\text { Carbonates and volcanic rock fragments, } \\
\text { poorly sorted }\end{array}$ \\
\hline Gmm & $\begin{array}{l}\text { Matrix supported } \\
\text { conglomerate }\end{array}$ & Massive & Lenticular & $\begin{array}{l}\text { Confined flow with high concentration of } \\
\text { suspended sediments and poor capacity for } \\
\text { size selection. }\end{array}$ & Volcanic rock fragments poorly sorted \\
\hline Sp & $\begin{array}{l}\text { Coarse to medium } \\
\text { sandstone }\end{array}$ & Tangential croos-bedding & Diffuse & $\begin{array}{l}\text { Unidirectional migration of subaqueous three- } \\
\text { dimensional dunes }\end{array}$ & $\begin{array}{l}\text { They are rare in the section. Presence of } \\
\text { Traction-carpets }\end{array}$ \\
\hline Sm & $\begin{array}{l}\text { Coarse to fine } \\
\text { sandstone }\end{array}$ & Massive & Tabular-Lenticular-Diffuse & $\begin{array}{l}\text { Product of a rapid deposition process during } \\
\text { periods of high discharge of water and sediments }\end{array}$ & $\begin{array}{l}\text { Carbonates and volcanic rock fragments, } \\
\text { traction-carpets, bioturbation and carbonate } \\
\text { nodules in the fine fraction }\end{array}$ \\
\hline Sh & $\begin{array}{l}\text { Medium to fine } \\
\text { sandstone }\end{array}$ & Horizontal lamination & Diffuse & Transport in conditions of high flow regime & \\
\hline Fm & Mudstone & $\begin{array}{l}\text { Massive, in some cases } \\
\text { with incipient parallel } \\
\text { stratification }\end{array}$ & Tabular-mantiform & $\begin{array}{l}\text { Decanting of fine material produced during the } \\
\text { final stage of decay in flow velocity }\end{array}$ & $\begin{array}{l}\text { Partially covered, little compaction, undiffe- } \\
\text { rentiated bioturbation }\end{array}$ \\
\hline Fl & Mudstone & Horizontal lamination & Tabular-Diffuse & Suspension load fall-out of mud & \\
\hline Fr & Mudstone & $\begin{array}{l}\text { Parallel and ripple cross } \\
\text { lamination. }\end{array}$ & Mantiform & Suspension load fall-out of mud & Undifferentiated bioturbation \\
\hline
\end{tabular}


TABLE 2. MODAL COMPOSITION OF THE ANALYZED SAMPLES.

\begin{tabular}{|c|c|c|c|c|c|c|c|c|c|c|c|}
\hline & \multicolumn{10}{|c|}{ SAMPLES-VEGA GRANDE ( $\%$ in weight) } \\
\hline & & VG1 & VG2 & VG3 & VG4 & VG5 & VG8 & VG9 & VG13 & VG16 & VG17 \\
\hline \multirow{4}{*}{ QUARTZ (Q) } & Qf & 24 & 9.25 & 27.5 & 30.75 & 26.5 & 23 & 31 & 29.5 & 11 & 27.75 \\
\hline & Qo & 6.5 & 0.25 & 1.5 & 3.75 & 5 & 9 & 1 & 0.75 & 3 & 5.5 \\
\hline & Qv & 2.75 & 3.75 & 1.75 & 5.25 & 1 & 1.5 & 2.5 & 3.25 & 0 & 1 \\
\hline & Qp & 4.25 & 9 & 7 & 5.5 & 5 & 3.25 & 4 & 4 & 1.25 & 8.5 \\
\hline \multirow{5}{*}{ FELDSPAR $(\mathbf{F}=\mathbf{K}+\mathbf{P})$} & $\mathbf{F k}$ & 8.75 & 2 & 2.25 & 6 & 7 & 3.75 & 5.5 & 5.5 & 4.75 & 8.75 \\
\hline & Fpl & 10.5 & 2 & 3.75 & 3 & 6.5 & 8 & 4.5 & 5.25 & 3.5 & 2.5 \\
\hline & Fkp & 0 & 2.25 & 0.75 & 0.25 & 0 & 0 & 0.25 & 0 & 1 & 1.5 \\
\hline & Fc & 0 & 0 & 0 & 0 & 0 & 0 & 0 & 0 & 2.25 & 0 \\
\hline & FPp & 0 & 1.5 & 0.5 & 0.75 & 0 & 1 & 0 & 0.25 & 1.75 & 0.5 \\
\hline \multirow{10}{*}{ LITHICS (L) } & Lpg & 13.25 & 9.75 & 13 & 15.75 & 9.25 & 6.5 & 13.75 & 10.25 & 4 & 6.5 \\
\hline & Lps & 3.75 & 3.75 & 0.25 & 0.75 & 4.25 & 13.5 & 8 & 4.75 & 0.5 & 2.25 \\
\hline & Lpp & 9.25 & 8.5 & 0 & 0.25 & 8.75 & 10 & 0 & 2.5 & 0 & 0.25 \\
\hline & Lpl & 0 & 0 & 0.5 & 0 & 0 & 0 & 0 & 0 & 0.25 & 0 \\
\hline & Lpm & 0.25 & 0 & 0 & 0 & 1.5 & 0.75 & 0 & 0 & 0.25 & 1 \\
\hline & Lc & 0 & 0 & 0 & 0 & 0 & 0 & 0 & 0 & 34.25 & 0 \\
\hline & Ls & 0.75 & 3 & 2.75 & 3 & 0.75 & 0 & 0.75 & 1.75 & 4.75 & 3.25 \\
\hline & $\mathbf{L p}$ & 0 & 0 & 0 & 0 & 0 & 0.5 & 0.25 & 0 & 0 & 0 \\
\hline & Lm & 0.75 & 1 & 3.25 & 1.5 & 1.75 & 2 & 1 & 0.5 & 0 & 0 \\
\hline & $\mathbf{L a}$ & 8 & 11 & 8 & 7 & 9 & 4.75 & 4 & 3.25 & 5.25 & 8.75 \\
\hline \multirow{5}{*}{ CEMENTS } & $\mathrm{Cc}$ & 6.25 & 0.5 & 0 & 0 & 2 & 1.75 & 8 & 3.25 & 0.5 & 0 \\
\hline & $\mathrm{Ca}$ & 0 & 1.25 & 4 & 1.75 & 2.25 & 0.75 & 0.5 & 0.25 & 0.25 & 0.75 \\
\hline & Cf & 0 & 3.25 & 2.75 & 1.5 & 0 & 0 & 4.75 & 2.5 & 3.75 & 1.25 \\
\hline & Ccar & 0.5 & 24.75 & 3.75 & 2.5 & 5.75 & 4.5 & 2.25 & 10.75 & 15.25 & 2.25 \\
\hline & Co & 0 & 0.5 & 0 & 1.75 & 0 & & 1 & 0.5 & 0 & 0 \\
\hline \multirow{4}{*}{ OTHERS } & $\mathbf{M}$ & 0.25 & 0 & 1 & 0.25 & 0.25 & 0 & 0 & 0.25 & 0 & 0.25 \\
\hline & Op & 0 & 1 & 0.25 & 1.75 & 1.25 & 0.75 & 0.75 & 0.75 & 0.25 & 2.5 \\
\hline & Om & 0 & 0 & 0 & 0 & 0.5 & 0 & 0 & 0 & 0 & 0 \\
\hline & $\mathbf{O}$ & 0.25 & 1.75 & 15.5 & 7 & 1.75 & 4.75 & 6.25 & 10.5 & 2.25 & 15 \\
\hline \multicolumn{12}{|c|}{ RECALCULATED VALUES } \\
\hline & Qt & 40.4 & 33.2 & 51.9 & 54.2 & 43.5 & 42 & 50.3 & 52.4 & 19.6 & 54.8 \\
\hline & $\mathbf{F t}$ & 20.8 & 11.6 & 10 & 12 & 15.7 & 14.6 & 13.4 & 15.4 & 17 & 17 \\
\hline & $\mathbf{L t}$ & 38.8 & 55.2 & 38.1 & 33.8 & 40.9 & 43.4 & 36.3 & 32.2 & 63.4 & 28.2 \\
\hline & Qm & 35.8 & 19.8 & 42.2 & 47.5 & 37.7 & 38.2 & 45.1 & 46.9 & 18 & 43.9 \\
\hline & $\mathbf{L}+\mathbf{Q p}$ & 43.4 & 68.7 & 47.8 & 40.5 & 46.7 & 47.2 & 41.6 & 37.8 & 65 & 39.1 \\
\hline
\end{tabular}

Qf: non-ondulatory monocrystalline quartz; Qo: undulatory monocrystalline quartz; Qv: quartz on volcanic rock grain; Qp: polycrystalline quartz; Fk: alkaline feldspar; Fpl: plagioclase feldspar; Fkp: alkaline feldspar on paleovolcanic lithic grain; Fc:feldspar replaced by calcite; FPp: plagioclase on paleovolcanic lithic grain; Lpg: granular texture on paleovolcanic lithic grain; Lps: serial texture on paleovolcanic lithic grain; Lpp: pyroclastic lithic grain; Lpl: lathwork texture on paleovolcanic texture; $\mathbf{L p m : ~ m i c r o l i t i c ~}$ texture on paleovolcanic lithic grain; Lc: carbonate lithic grain; Ls: another sedimentary lithic grain (generally siltstone); Lp: plutonic lithic grain; Lm: metamorphic lithic grain; La: altered and undetermined lithic grain; Cc: zeolitic cement; Ca: argillaceous cement; Cf: iron cement; Ccar: calcareous cement; Co: other cements; M-micas; Op: opaques; Om: other minerals; O: porosity. Recalculated values: Qt: total quartz; Ft: total feldspar; Lt: total lithics; Qm: monocrystalline quartz; L+Qp: lithics + plycrystalline quartz. 


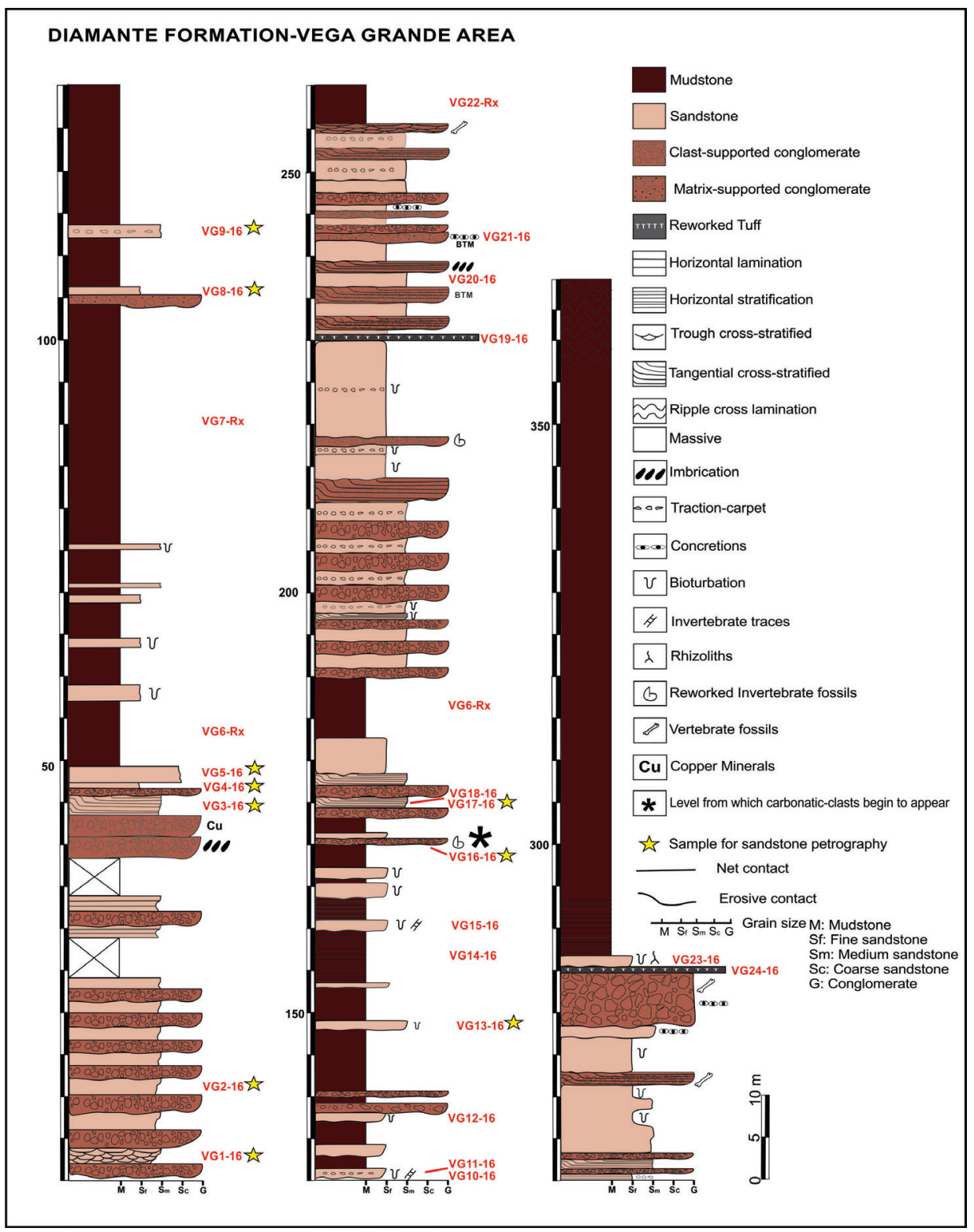

FIG. 3. Stratigraphic section from Vega Grande area. The yellow star symbols represent the position of the samples gathered for petrographic analyses and characterization.

important thickness (from 1 to $80 \mathrm{~m}$ ) representing the major type of deposit in Vega Grande area (Fm, Fl, Fr).

\subsection{Facies Association}

From the facies analysis, two facies associationsChannels and Bars (FAI) and Floodplain (FAII) - were established (Gómez et al., 2016a, b).
The channels and bars association (FAI) is evidenced by the presence of strata with lenticular and in some cases tabular and chaotic geometry, of variable extension and thickness. The basal contact of this facies association is erosive, followed by conglomerates and medium to coarse-grained sandstones, mainly massive with tangential and festoon cross-bedding with restricted levels with 
imbricated clasts (Fig. 4). Different sedimentary rock bodies were observed in this facies association, assigned to deposits of: non-channelized floods, hyper-concentrated flows, non-channelized viscosity flows, channel and transverse-longitudinal bars (Miall, 2014) (Fig. 5). Regarding the channelized deposits, both the predominance of the massive facies and the scarce levels with imbricated clasts hindered the paleocurrent measurement in the Vega Grande section (Figs. 4C-D). The channel-stacking and the presence of cut and fill structures represent the superposition of several events, reflecting the presence of multiepisodic filling of channels. The lateral development of the channels is limited to a few dozen meters. No lateral accretion surfaces were observed; however, the conglomerate and sandy facies
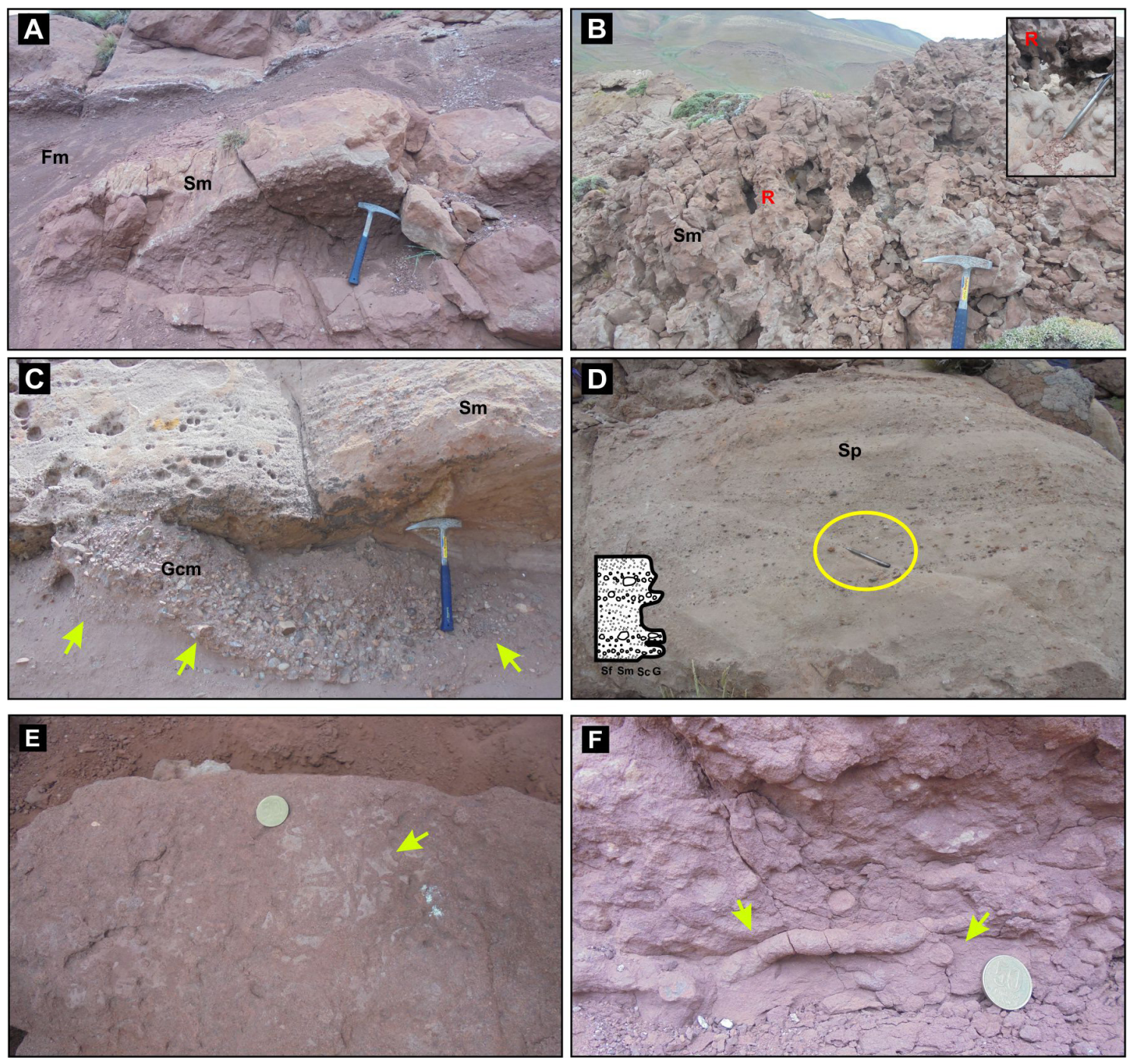

FIG. 4. Field photos of the lithofacies and facies associations present in the study area. A. Massive sandstone facies (Sm) in beds of lenticular geometry interspersed with finer levels of floodplain (Fm); B. Massive sandstone facies (Sm) with rhizoliths (R) on the top of Vega Grande stratigraphic section. Above to the right a detail of trace fossils observed; C. Clast-supported massive conglomerate facies (Gcm) with cutt and fill structures (yellow arrow); D. Tangential cross-bedding sandstone facies (Sp), showing traction-carpets. In the left corner, the schematization of this type of deposit. E-F. Massive sandstone facies (Sm) with horizontal and vertical undifferentiated tubes (yellow arrow). 


\begin{tabular}{|c|c|c|c|c|c|}
\hline $\begin{array}{l}\text { FACIES ASSOCIATION } \\
\text { (FA) }\end{array}$ & & DEPOSIT & $\begin{array}{l}\text { BEDDING AND SEDIMENTARY } \\
\text { STRUCTURES }\end{array}$ & SEDIMENTARY BODIES & $\mathbf{N}^{\circ}$ \\
\hline \multirow{7}{*}{$\begin{array}{l}\text { CHANNELS } \\
\text { AND BARS (FAl) }\end{array}$} & \multirow{3}{*}{ 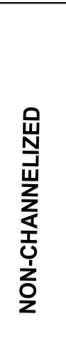 } & \multirow{3}{*}{ 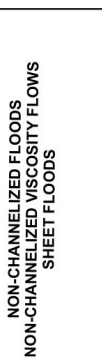 } & $\begin{array}{l}\text { MASSIVE } \\
\text { Conglomerates }\end{array}$ & 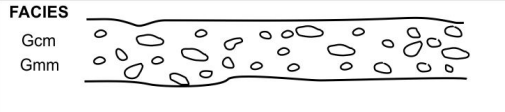 & 1 \\
\hline & & & $\begin{array}{l}\text { MASSIVE } \\
\text { with isolated clasts }\end{array}$ & 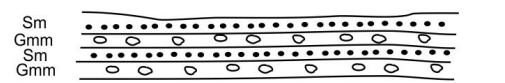 & 2 \\
\hline & & & $\begin{array}{l}\text { MASSIVE } \\
\text { Sandstones }\end{array}$ & sm $\quad \therefore \because \therefore \because \because$ & 3 \\
\hline & \multirow{4}{*}{ 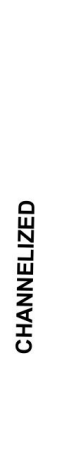 } & \multirow{4}{*}{ 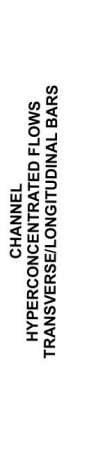 } & $\begin{array}{l}\text { TANGENTIAL CROOS-BEDDING } \\
\text { Conglomerates and Sandstones }\end{array}$ & 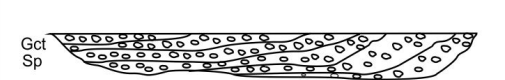 & 4 \\
\hline & & & \begin{tabular}{|c|} 
MASSIVE \\
Conglomerates and Sandstones
\end{tabular} & 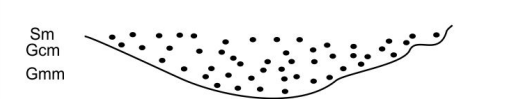 & 5 \\
\hline & & & $\begin{array}{l}\text { TYPICAL DEPOSITIONAL } \\
\text { CYCLES } \\
\text { Gmm+Gcm+Sp+Sm }\end{array}$ & 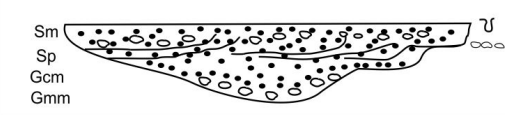 & 6 \\
\hline & & & MULTI-STOREY FILL & 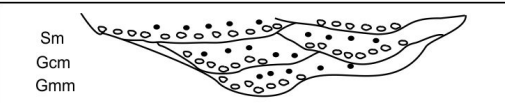 & 7 \\
\hline \multirow{2}{*}{ FLOODPLAIN (FAII) } & \multirow{2}{*}{ 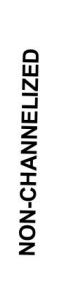 } & \multirow{2}{*}{ 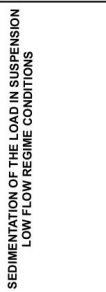 } & $\begin{array}{l}\text { PARALLEL LAMINATION } \\
\text { AND CURRENT RIPLES }\end{array}$ & 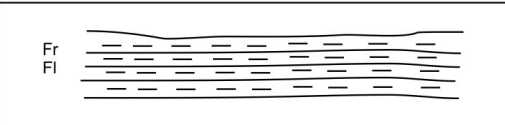 & 8 \\
\hline & & & MASSIVE & $\overline{E \Xi \Xi \Xi}$ & 9 \\
\hline
\end{tabular}

FIG. 5. Scheme showing Facies Association, Types of Deposits (divided on channelized and non-channalized) and their respective geometries (Miall, 2014 and references therein).

with current sedimentary structures (Gct, Sp) suggest the filling of channels with longitudinal or transverse bar formation. The lack of 3-D channelized bodies makes it difficult to observe or define the type of bar. Bioturbation, mottling, carbonate nodules and calcrete levels on the most fine-grained facies are common. Traces assigned to Scoyenia, Taenidium, Arenicolites, Skolithos, Rhizoliths and horizontal and vertical undifferentiated tubes have been identified (Fig. 4B, E-F and Fig. 6B). The non-channelized floods and viscosity flow deposits are common along the entire sequence. One of the features of these deposits is the presence of isolated 2 to $5 \mathrm{~cm}$ long clasts in beds that present a diffuse lamination or stratification (Fig.4D). One of the particularities of this facies association is the difference observed in clast composition. In the lower levels of the section, the conglomerates are essentially composed by volcanic rock clasts, while towards the top there are many limestone clasts and scarce undifferentiated and reworked fossil invertebrates (Fig. 6A). The presence of limestone clasts is also identified and verified in the petrography of sandy levels.

The floodplain deposits (FAII) are composed by red shales which could indicate low-flow regime conditions favoring the sedimentation of the load in suspension during the decrease in flow velocity. The friable character of these rocks and the fact that they are mainly covered, obscure observations regarding the geometry of the banks and the nature 

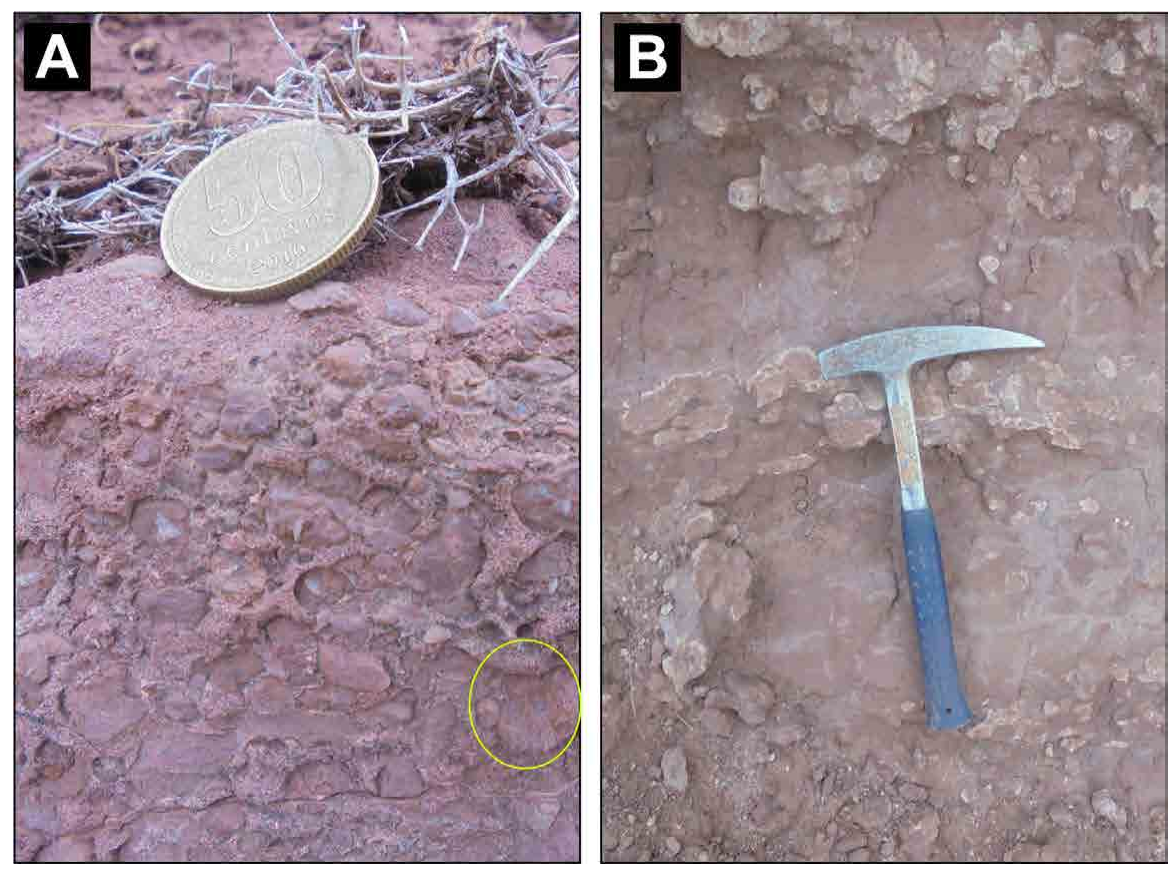

FIG. 6. Field photos of the facies present in the study area. A. Conglomerate composed almost exclusively of carbonate clasts. The yellow circle indicates the presence of an undifferentiated invertebrate remains. B. Carbonate nodules and calcrete levels in floodplain facies.

of their contacts. One of the features of the floodplain deposits is the presence of isolated channelled-sandy bodies (Fig. 7D-E).

\subsection{Petrography}

The Upper Cretaceous sandstones of the Diamante Formation in the area of Vega Grande are feldspatic litharenites mainly $\mathrm{Q}_{48} \mathrm{~F}_{16} \mathrm{~L}_{36}$ and scarce litharenites $\mathrm{Q}_{35} \mathrm{~F}_{13} \mathrm{~L}_{52}$ (Table 2, Fig. 8) with percentages of matrix less than $10 \%$ of the whole rock.

The average quartz proportion in the samples is $55 \%$ and the predominant variety is the monocrystalline with straight extinction one. Quartz with ondulatory extinction (4\%) was also recognized, as well as quartz as a fragment of a volcanic rock (on average $2 \%$ ). Embayment quartz with volcanic matrix preservation was observed in samples VG1, VG4 and VG17. No clear tendency towards the base or the top regarding the quantity of quartz could be observed in the analyzed stratigraphic section, although the samples with an important proportion of altered lithic clasts or carbonates (samples VG2 and VG16) recorded a low quantity (Fig. 8F). The polycrystalline quartz proportion (on average $5 \%$ ) is relatively low throughout the section.

Regarding alkaline feldspar and plagioclase, the average proportions are 5.4 and $4.9 \%$ respectively, and normally show sericitic and argillic alteration. In addition alkaline feldspar and plagioclase (on average $1 \%$ ) were recognized as volcanic rock crystals and in some cases calcite replacements.

The lithic fragments make up for $41 \%$ of the clastic fraction, a high average percentage compared to the quartz and feldspar. These characteristic were also noticed by Balgord and Carrapa (2016) for the rocks of the Diamante Formation located around $100 \mathrm{~km}$ to the south. The lithics have an angular to subangular shape, they appear in varied sizes (on average $0.5-10 \mathrm{~cm}$ ), and mainly belong to volcanic rocks, more specifically paleovolcanic, according to the criteria of Critelli e Ingersoll (1995). In almost all of the samples, fragments of volcanic rocks with felsitic, granular, micro granular and serial textures were predominant, although volcanic fragments with pilotaxic texture and pyroclastic fragments were observed to a lower extent. In addition, great proportions $(34.5 \%)$ of calcareous lithic fragments 

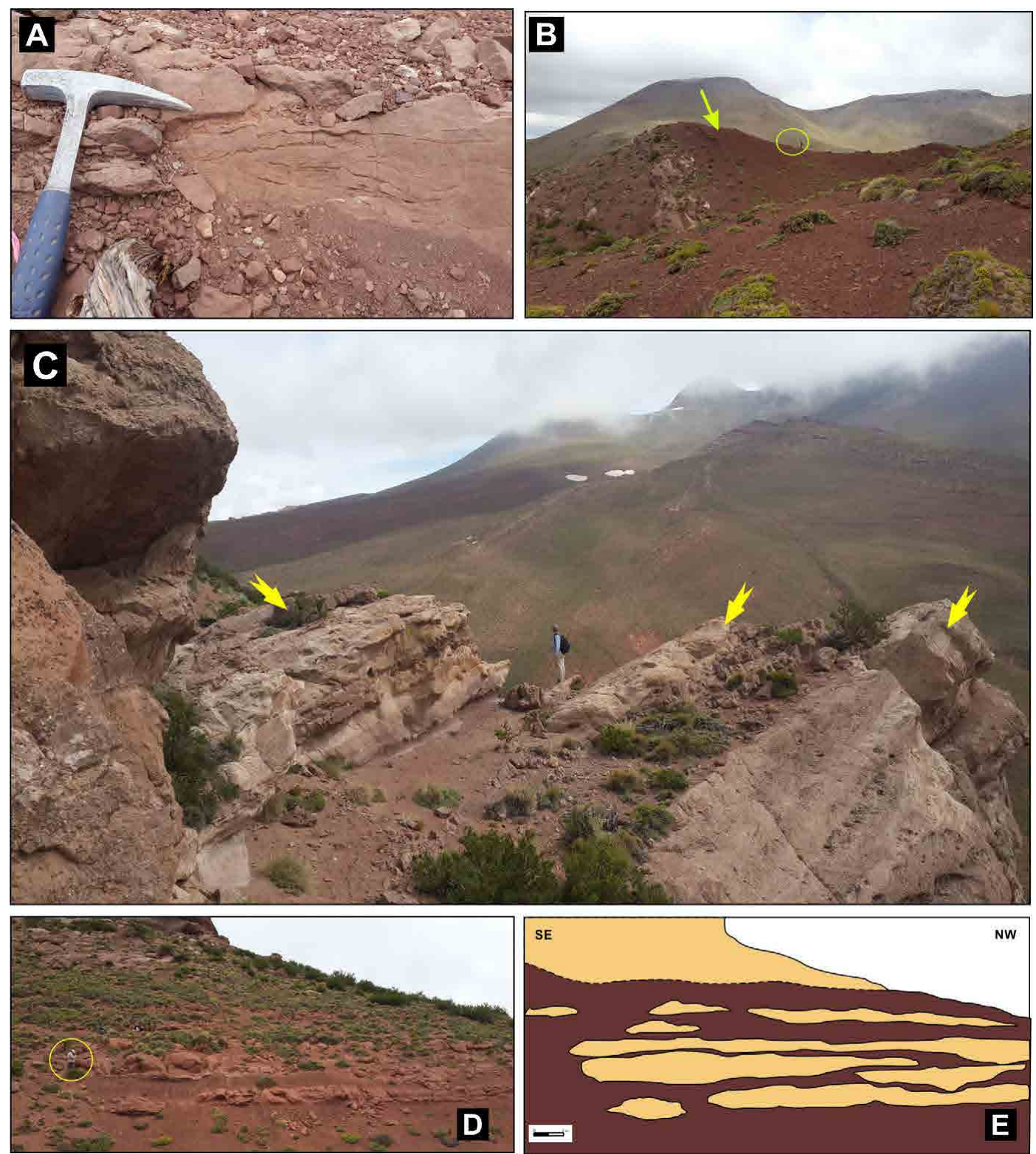

FIG. 7. Floodplain facies association (FA II). A. Parallel lamination and current ripples on sandstone facies; B. Floodplain deposits (yellow arrow) on the top of Vega Grande stratigraphic section (the yellow circle indicates the position of a person $1.80 \mathrm{~m}$ tall); C. Stacking of channels and bars (FA I); D. Panoramic view showing the intercalation of the two facies associations present in the study area; E. Redraw of the previous photo. The layout and geometry of the fluvial channels are observed, and how they affect the floodplain. Yellow: Channels and bars facies association; Red: Floodplain facies association.

in the mid part of the section (sample VG16) were recognized. Large amounts of altered lithic fragments and pseudomatrix (VG2) were also identified. Sedimentary lithic grains, metamorphic rock fragments and plutonic rock clasts were also observed in low proportions. The most common type of cement is calcareous, followed by zeolitic, ferruginous and argillaceous types. Cement occurs as pore filling, pore lining and scarce poikilotopics (Fig. 8E). The alizarine red and potassium ferricyanure stain allowed 

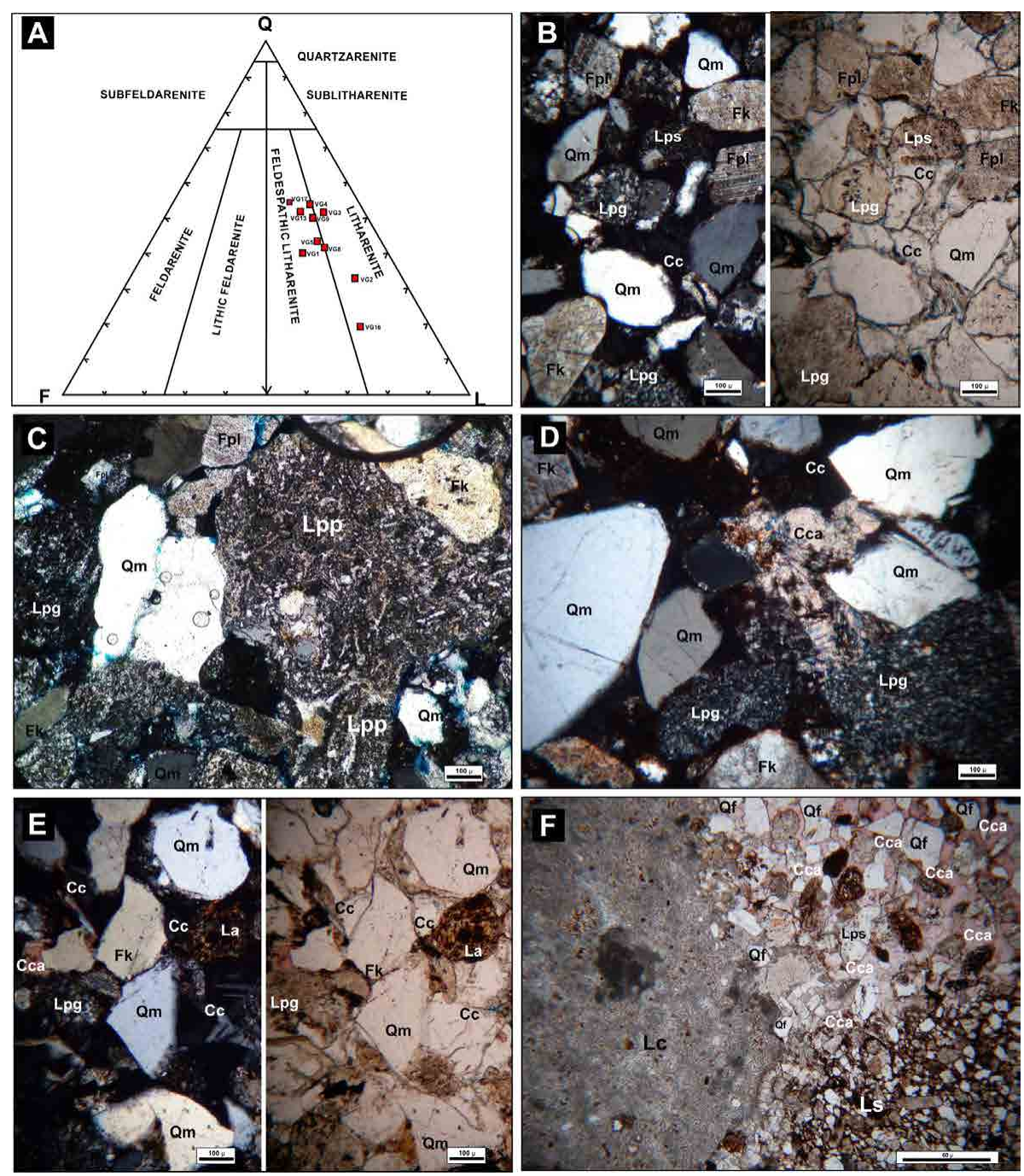

FIG. 8. A. Sandstone classification QFL plot (Folk et al., 1970) of the analyzed samples; B. Photomicrographs of VG1 sample, it is composed of monocrystalline quartz $(\mathbf{Q m})$, alkaline feldspar $(\mathbf{F k})$, plagioclase (Fpl), granular (Lpg) and serial (Lps) paleovolcanic lithic fragments. It is also observed analcime as a type of zeolitic cement (Cc). Photomicrographs on PN and CN. Scale: 100 microns; C. Photomicrograph of VG4 sample. It is composed of monocrystalline quartz (Qm), alkaline feldspar (Fk), plagioclase (Fpl) and pyroclastic paleovolcanic lithic fragment (Lpp), with altered vitreous shard. Photomicrographs on CN. Scale: 100 microns; D. Photomicrograph of VG8-16 sample. It is composed of monocrystalline quartz (Qm), alkaline feldspar (Fk), granular paleovolcanic lithic fragment (Lpg), zeolitic cement (Cc) and calcite cement (Cca). Scale: 100 microns; E. Photomicrographs of VG9 sample. It is composed of monocrystalline quartz (Qm), alkaline feldspar (Fk), altered lithic fragment (La) and granular paleovolcanic lithic fragment (Lpg). Photomicrographs on PN and CN. Scale: 100 microns; F. Photomicrograph of VG16-16 sample. It is made of high percentage of limestone fragments (Lc). Scale: 60 microns. PNP: parallel nichols; CN: crossed nicols.

establishing that carbonate cement is non-ferrous calcite. The average percentage of zeolitic cement in the samples is low $(2 \%)$, but in some samples such as VG9 and VG8, that percentage rises due to the presence of analcime occurring as pore filling cement and in subhedral crystals related to calcite cementation (Fig. 8D).

The minor constituents are the micas, opaques, along with heavy minerals such as zircons, among others. Values drawn from modal analysis were plotted 
into the Folk et al. (1970) diagram for sandstone classification (Fig. 8A).

\subsection{Provenance}

Sandstones modal analysis will be used in this study to identify the source area. The recalculated modal composition for the sandstones (Table 2) was plotted on the provenance graphs of Dickinson et al. (1983). Both graphs indicate that the analyzed samples mostly fall in the recycled orogen (Fig. 9A) and transitional recycled (Fig. 9B) fields, although some of them have a transitional and mixed arc provenance (Fig. 9B). Embayment on the quartz supports active volcanic processes, while analcime as cement (sample VG9) indicates volcanic material alterations. The latter appears filling pores and completely sealing the porosity present.

\section{Discussion}

The paleoenvironmental interpretation of the Diamante Formation deposits in the studied area suggests a braided fluvial system of moderate sinuosity evolving over time towards an anastomosing fluvial system (Miall, 1996, 2014 and references therein). The braided system is constituted by the multiepisodic conglomeratic-sandy channels, undifferentiated bars (longitudinal/transverse) and sandy overflow deposits. The internal characteristics and depositional geometry suggest that the multiepisodic conglomeratic-sandy channels were generated by a confined flow with a high concentration of suspended sediment and limited capacity of size selection (Coussot and Meunier, 1996). Regarding sandy overflow deposits, these represent non-channelized sheets probably associated with hyperconcentrated-flow deposits of stream floods. The isolated clasts in these deposits are interpreted as traction-carpets deposited by a high-density gravel turbidity current (Lowe, 1982; Mutti, 1992). The stacking of successive strata could be linked to the cyclical repetition of this process (Lowe, 1982). In addition, the size of the sediment grain (mainly pebbles) and the thickening or thinning of the traction-carpets enabled the recording of temporal fluctuations of the flow discharges due to the instability and lack of continuity of such conditions (Sohn, 1997). On the other hand, the presence of the Rhizoliths at the top of this unit, together with a high bioturbation index and calcretes, is an evidence of subaereal exposition and pedogenetic processes. This would be related to a period of tectonic stability, climatic variation, relief changes or a combination of all. Based on the latter, the presence of topographic barriers related with the Andean uplift to the west of the study area (Muñoz et al., 2018) could be the reason of soils genesis and the pedogenetic processes in the synorogenic deposits located on the foredeep. The isolated channelized-sandy bodies
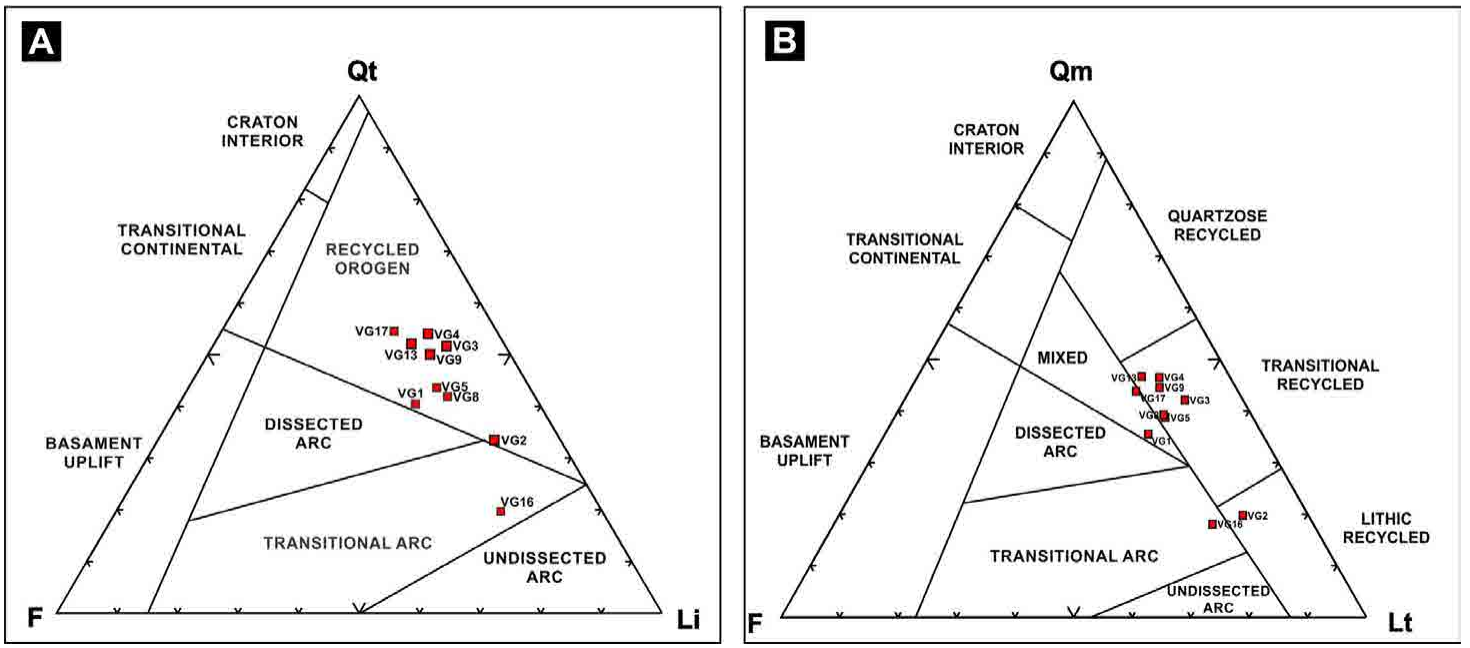

FIG. 9. QFL and QmFLt plots of sandstones from Diamante Formation to discriminate provenance areas. A. QFL diagram from Dickinson et al. (1983). B. QmFLt from Dickinson et al. (1983). Q: total quartz; F: total feldspar; L: total lithic fragments; Qm: monocrystalline quartz; Lt: total lithic fragments plus polycrystalline quartz. 
on the floodplain deposits are probably associated with one of the most important processes according to Miall (2014) occurring in the floodplain, i.e., the avulsion. River avulsion is the shifting of channels into new positions on the floodplain. Avulsion is typically initiated by localized erosion of a channel bank, forming a crevasse channel, which diverts some of the discharge and sediment load from the main channel onto the floodplain.

The term "anastomosing fluvial system" is used in this interpretation for an interconnected network of relatively deep and narrow (low width/depth ratios) channels (Miall, 2014). Separating the channels are stable banks (floodplain deposits) composed of fine-grained sediment (silt/clay) with immature paleosoils and important bioturbation. On the other hand, the features of the described facies, their lateral and vertical relationship and the sedimentary processes reflected in these deposits partly coincide with the medial zone of fluvial fan or Distributary Fluvial System (DFS) models. Those facies models were described by several authors over the past few years (Nichols and Fisher, 2007; North and Warwick, 2007; Cain and Mountney, 2009; Hartley et al., 2010; Weissmann et al., 2010; Moscariello, 2017; Santi Malnis et al., 2018). More stratigraphic sections are needed to link the facies described in Vega Grande with a depositional environment of fluvial fan system or DFS. The addition of more localities will allow a better understanding of the sedimentological paleoenvironment, enabling the comparison with other models.

The petrographic analysis, the composition and proportion of lithic fragments in the Upper Cretaceous sandstones indicate that they are not only associated to the nature and tectonic history of the input area, but they also reflect particular transport, weathering and climate, which can be interpreted as semi-arid due to the high amount of lithic fragments (Potter, 1994) and calcretes in the paleosoils. Regarding the proportions and relationships between the different types of cement, the diagenetic conditions that prevail after the deposition could be established in a preliminary way showing that the eodiagenetic were the predominant conditions, extending in some cases to shallow mesodiagenetic. Carbonate cementation may be early or late. Early cementation tends to be linked to wandering water and/or phreatic evaporation processes, while mesogenetic cementation is favoured by temperature rise, and hence burial deepness.
Analcime would have had an authigenic origin due to the replacement of both pyroclastic lithics and vitroclastic fragments. Some samples show that analcime is associated with carbonate cement. This behavior suggests a rapid change in the chemistry of pore waters. On the other hand, the presence of argillaceous and ferruginous cement in some samples also indicates a change in the chemistry of pore waters, on early to late eodiagenetic conditions.

From the petrographic provenance analysis- and based on the geological context of the area- and the presence of high content of paleovolcanic lithic fragments indicating the erosion of a volcanic arc together with the presence of carbonatic lithic fragments (sample VG16), provenance from the western Andean orogen is clear. This suggests a stage of active deformation and important uplift that would have been coeval with the erosion of an older orogen located to the east of the study area. Related to this, Broens and Pereira (2005) recognized fragments of limestone from Mendoza Group in the Neuquén Group (upper section according to these authors) at localities $25 \mathrm{~km}$ to the northwest of our study area, near to the confluence between the Diamante River and Borbollón River. Borghi et al. (2017) also described fragments of limestone in conglomerates of Neuquén Group $170 \mathrm{~km}$ to the south of the study area. In an area near Malargüe, Balgord and Carrapa (2016) described a change in sandstone composition of the Diamante Formation, from volcanic lithic on the bottom to a higher content of sedimentary lithic fragments towards the mid and upper parts. These authors interpreted the variation in sandstone composition as a change in the source area, first from the east and then from the west, due to the migration of the forebulge during the eastward migration of the thrust front. It is important to consider that the volcanic rock fragments could be associated with the erosion of the San Rafael Block, another positive area located towards the east. Input from both magmatic arc and recycled orogen is a common feature in foreland basins, especially in orogenic systems involving active magmatic arcs (Scasso and Limarino, 1997). In these conditions, the detrital modes will reflect transitional characteristics within the field of recycled orogens, just as shown in Dickinson et al. (1983) diagrams (Fig. 9). The presence of at least two levels of reworked tuffs in the Vega Grande area together with the presence of the analcime cementation is coherent with the 
presence of active volcanism near the area during Late Cretaceous.

\section{Conclusions}

The sedimentary rock sequence included in the Diamante Formation is interpreted as a braided fluvial system that evolved through time towards an anastomosing fluvial system. Yet, the possibility that these deposits were part of the middle sector of a fluvial fan system or DFS (Distributary Fluvial System) should not be discarded. The fluvial system is formed by multiepisodic conglomeradic-sandy channels, overflow and floodplain deposits, which record paleosols and important bioturbation. The petrographic analysis shows that the sandstones are mainly feldspatic litharenites (mostly $\mathrm{Q}_{48} \mathrm{~F}_{16} \mathrm{~L}_{36}$ ), and minor litharenites $\left(\mathrm{Q}_{35} \mathrm{~L}_{13} \mathrm{~L}_{52}\right)$, while the source area indicates provenance from a recycled orogen (diagram QFL) and transitional recycled orogen (diagram QmFLt). The latter could be associated with both the exhumation of the early Andean orogen located to the west, indicating a period of deformation and important uplift during its deposition, coeval with input from the northeastern border of the Neuquén Basin. The sudden change in predominance of the lithic fragments from paleovolcanic to carbonatic in the mid and upper part of the analyzed stratigraphic section allows inferring an important change in the polarity of the Neuquén Basin. This research reinforces the evidence of a deformation front located towards the west of the study area, which would have affected and exposed the sediments of the Mendoza Group. The potential uplifted structures that could have been the source of the clastic components of the Diamante Formation are probably related with the topographic barrier proposed by Muñoz et al. (2018) in the Chilean Andes at $\sim 35^{\circ} \mathrm{S}$. The presence of these limestone clasts could also be interpreted as resulting from a local base level change that generated a local input area. However, the latter looses importance due to the limestone clasts found in conglomerates from Diamante Formation and the Neuquén Group, both in the North and in the south of the study area.

\section{Acknowledgment}

This study was financially supported by UNRN-40A-321 project of the Universidad de Río Negro, Argentina, as well as by PICT 2013-0095 of the Agencia Nacional de
Promoción Científica y Tecnológica (Argentina). The authors want to acknowledge R. Ponti for the preparation of thin sections, M. Griffin for helping with the manuscript and M. de la Fuente for his help during the course of this research. We would like to thank L. Fennell for the corrections, comments, and suggestions that helped to improve this paper. Also, the authors would like to thank A. Encinas and an anonymous reviewer for their help to improve our manuscript, and W. Vivallo for his editorial work and help.

\section{References}

Aguirre-Urreta, M.B.; Pazos, P.J.; Lazo, D.G.; Fanning, C.M.; Litvak, V.D. 2008. First U-Pb SHRIMP age of the Hauterivian stage, Neuquén Basin, Argentina. Journal of South American Earth Sciences 26: 91-99.

Aguirre-Urreta, M.B.; Tunik, M.; Naipauer, M.; Pazos, P.; Ottone, E.; Fanning, M.; Ramos, V.A. 2011. Malargue Group (Maastrichtian-Danian) deposits in the Neuquén Andes, Argentina: Implications for the onset of the first Atlantic transgression related to Western Gondwana break-up. Gondwana Research 19: 482-494.

Armas, M.P.; Sánchez, M.L. 2013. Sedimentología y arquitectura de las dunas costeras de la Formación Allen, Grupo Malargüe, Cuenca Neuquina-Río Negro, Argentina. Revista Mexicana de Ciencias Geológicas 30: 65-79.

Asurmendi, E.; Sánchez, M.L.; Fennell, L. 2017. Neuquén Group (Upper Cretaceous): a case of underfilledoverfilled cycles in an Andean foreland basin, Neuquén basin, Argentina. Journal of South American Earth Sciences 80: 444-459.

Balgord, E.A.; Carrapa, B. 2016. Basin evolution of Upper Cretaceous-Lower Cenozoic strata in the Malargüe foldand-thrust belt: northern Neuquén Basin, Argentina. Basin Research 28 (2): 183-206.

Borghi, P.; Gómez Omil, R.; Fennell, L.; Folguera, A.; Naipauer, M. 2017. Nuevas evidencias del levantamiento del sur de los Andes Centrales ( $36^{\circ} \mathrm{S}$ ) durante la depositación del Grupo Neuquén. In Congreso Geológico Argentino, No. 20, Libro Digital: 2932-3697. Tucumán.

Bracaccini, O. 1970. Rasgos tectónicos de las acumulaciones mesozoicas en las provincias de Mendoza y Neuquén, República Argentina. Revista de la Asociación Geológica Argentina 25 (2): 275-284. Buenos Aires.

Broens, S.; Pereira, M. 2005. Evolución estructural de la zona de transición entre las fajas plegadas y corridas de Aconcagua y Malargüe Provincia de Mendoza. Revista de la Asociación Geológica Argentina 60 (4): 685-695. 
Cain S.A.; Mountney, N.P. 2009. Spatial and temporal evolution of a terminal fluvial fan system: the Permian Organ Rock Formation, South-east Utah. Sedimentology 56: 1774-1800. USA

Cazau, L.; Uliana, M. 1973. El Cretácico Superior continental de la Cuenca Neuquina. In Congreso Geológico Argentino, No. 5, Actas 3: 131-163. Córdoba.

Corbella, H.; Novas, F.E.; Apesteguía, S.; Leanza, H.A.; 2004. First fission-track age for the dinosaur-bearing Neuquén Group (Upper Cretaceous), Neuquén Basin, Argentina. Revista del Museo Nacional de Ciencias Naturales 6 (2): 227-232.

Coussot, P.; Meunier, M. 1996. Recognition, classification and mechanical description of debris flows. EarthScience Review 40: 209-227.

Cristallini, E.; Tomezzoli, R.; Pando, G.; Gazzera, C.; Martínez, J.M.; Quiroga, J.; Buhler, M.; Bechis, F.; Barredo, S.; Zambrano, O. 2009. Controles precuyanos en la estructura de la cuenca Neuquina. Revista de la Asociación Geológica Argentina 65 (2): 248-264.

Critelli, S.; Ingersoll, R.V. 1995. Interpretation of neovolcanic versus palaeovolcanic sand grains: an example from Miocene deep-marine sandstone of the Topanga Group (Southern California). Sedimentology 42: 783-804.

Cruz, C. 1993. Facies y estratigrafía secuencial del Cretácico superior en la zona del río Diamante, Provincia de Mendoza, Argentina. In Congreso Geológico Argentino, No. 12 y Congreso de Exploración de Hidrocarburos, No. 2, Actas 1: 46-54. Mendoza.

Di Giulio, A.; Ronchi, A.; Sanfilippo, A.; Tiepolo, M.; Pimentel, M.; Ramos, V.A. 2012. Detrital zircon provenance from the Neuquen Basin (south-central Andes): cretaceous geodynamic evolution and sedimentary response in a retroarc-foreland basin. Geology 40: 559-562.

Di Giulio, A.; Ronchi, A.; Sanfilippo, A.; Balgord, E.A.; Carrapa, B.; Ramos, V.A. 2016. Cretaceous evolution of the Andean margin between $36^{\circ} \mathrm{S}$ and $40^{\circ} \mathrm{S}$ latitude through a multi-proxy provenance analysis of Neuquén Basin strata (Argentina). Basin Research 29: 284-304.

Dickinson, W.R.; Beard, L.S.; Brakenridge, G.R.; Erjavec, J.L.; Ferguson, R.C.; Inman, K.F.; Knepp, R.A; Lindberg, F.A.; Ryberg, P.T. 1983. Provenance of North American Phanerozoic sandstones in relation to tectonic setting. Geological Society of America 94: 222-235.

Fennell, L.; Folguera, A.; Naipauer, M.; Gianni, G.; Rojas E.; Bottesi, G.; Ramos, V. 2017a. Cretaceous deformation of the southern Central Andes: synorogenic growth strata in the Neuquén Group $\left(35^{\circ} 30^{\prime}-37^{\circ} \mathrm{S}\right)$. Wiley, Basin Research 29 (S1): 51-72.
Fennell, L.; Naipauer, M.; Folguera, A. 2017b. El movimiento Intersenoniano de Pablo Groeber en el norte de Neuquén y Sur de Mendoza: bases de la primera orogenía andina. Revista de la Asociación Geológica Argentina 74: 59-73.

Folguera, A.; Bottesi, G.; Duddy, I.; Martín-González, F.; Orts, D.; Sagripanti, L.; Rojas Vera, E.A.; Ramos, V.A. 2015. Exhumation of the Neuquén Basin in the southern Central Andes (Malargüe fold and thrust belt) from field data and low-temperature thermochronology. Journal of South American Earth Sciences 64: 381-398.

Folk, R.L.; Andrews, P.B; Lewis, D.W. 1970. Detrital sedimentary rock classification and nomenclature for use in New Zeland. New Zeland Journal of Geology and Geophysics 13: 937-968.

Garrido, A.C. 2010. Estratigrafía del Grupo Neuquén, Cretácico Superior de la Cuenca Neuquina (República Argentina): Nueva propuesta de ordenamiento litoestratigráfico. Revista del Museo Argentino de Ciencias Naturales, Nueva Serie 12 (2): 121-177.

Giambiagi, L.B.; Tunik, M.; Barredo, S.; Bechis, F.; Ghiglione, M.; Álvarez, P.; Drosina, M. 2009. Cinemática de apertura del sector norte de la cuenca Neuquina. Revista de la Asociación Geológica Argentina 65 (1): 140-153.

Gómez, R.; Tunik, M.; Casadío, S. 2016a. Análisis de facies del Grupo Neuquén, Cretácico Superior, en el área Vega Grande, Mendoza, Argentina. Congreso. In Congreso Latinoamericano de Sedimentología, No. 7 y Reunión Argentina de Sedimentología, No. 15, Acta 1: 86 p. Santa Rosa.

Gómez, R.; Tunik, M.; Casadío, S. 2016b. Icnología del Grupo Neuquén (Cretácico Superior), Vega Grande, Mendoza: caracterización e importancia paleoambiental. Congreso. In Congreso de la Asociación Paleontológica Argentina, No. 11, Acta 1: 52 p. General Roca.

Groeber, P. 1946. Observaciones geológicas a lo largo del meridiano $70^{\circ} .1$ Hoja Chos Malal. Revista de la Sociedad Geológica Argentina 1 (3): 117-208. Reimpreso en Asociación Geológica Argentina, Serie C, Reimpresiones (1980) 1: 1-174. Buenos Aires.

Gulisano, C.A.; Gutiérrez Pleimling, A.R. 1994. The Jurassic of the Neuquén Basin: Mendoza Province. Asociación Geológica Argentina, Field Guide, Special Publication 159: 103 p. Buenos Aires.

Hartley, A.J.; Weissmann, G.S.; Nichols, G.J.; Warwick, G.L. 2010. Large distributive fluvial systems: characteristics, distribution and controls on development. Journal of Sedimentary Research 80: 167-183. doi: 10.2110/ jsr.2010.016. 
Horton, B.K.; Fuentes, F.; Boll, A.; Starck, D.; Ramírez, S.; Stockli, D. 2016. Andean stratigraphic record of the transition from backarc extension to orogenic shortening: A case study from the northern Neuquén Basin, Argentina. Journal of South American Earth Sciences 71: 17-40. doi: 10.1016/j.jsames.2016.06.003.

Howell, J.A.; Schwarz, E.; Spalletti, L.; Veiga, G.D. 2005. The Neuquén Basin: an overview. In The Neuquén Basin: a Case Study in Sequence Stratigraphy and Basin Dynamics (Veiga, G.; Spalletti, L.A.; Howell, J.A.; Schwarz, E.; editors). The Geological Society, Special Publication 252: 1-14.

Leanza, H.A. 2003. Las sedimentitas huitrinianas y rayosianas (Cretácico Inferior) en el ámbito central y meridional de la Cuenca Neuquina, Argentina. Servicio Geológico Minero Argentino, Serie Contribuciones Técnicas-Geología 2: 1-31.

Leanza, H.A. 2009. Las principales discordancias del Mesozoico de la Cuenca Neuquina según observaciones de superficie. Revista Museo Argentino Ciencias Naturales, Nueva Serie 11 (2): 145-184.

Legarreta, L.; Gulisano, C. 1989. Análisis estratigráfico secuencial de la Cuenca Neuquina (Triásico superiorTerciario inferior). In Cuencas Sedimentarias Argentinas (Chebli, G.; Spalletti, L.; editores). Correlación Geológica 6: 221-243.

Llambías, E.J.; Quenardelle, S.; Montenegro, T. 2003. The Choiyoi Group from central Argentina: A subalkaline transitional to alkaline association in the craton adjacent to the active margin of the Gondwana continent. Journal of South American Earth Science 16: 243-257.

Lothari, L.; Gómez, R.; Tunik, M.; Toffani, M. 2018. Análisis sedimentológico y petrográfico de las Formaciones Rayoso y Diamante en el norte de la cuenca Neuquina, sur de Mendoza. In Congreso de Exploración y Desarrollo de Hidrocarburos, No. 10, Libro de actas, Programa de Estudiantes: 91-108. Mendoza.

Lowe, D.R. 1982. Sediment gravity flows: II . Depositional models with special reference to the deposits of highdensity turbidity currents. Journal of Sedimentary Petrology 52: 279-297.

Martínez, A.; Giambiagi, L. 2010. Evolución petrológica y geoquímica del magmatismo bimodal Permo-Triásico del Grupo Choiyoi en el cordón del Portillo, Mendoza, Argentina. Universidad de Oviedo, Trabajos de Geología 30: 432-451.

Mescua, J.; Giambiagi, L.B.; Ramos, V.A. 2013. Late cretaceous uplift in the Malargüe fold-and-thrust belt $\left(35^{\circ} \mathrm{S}\right)$, southern central Andes of Argentina and Chile. Andean Geology 40: 102-116. doi: 10.5027/andgeoV40n1-a05.
Miall, A.D. 1996. The Geology of Fluvial Deposits, Vol. 575. Springer. Berlin.

Miall, A.D. 2014. Fluvial Depositional Systems. Springer: 316 p. New York.

Moscariello, A. 2017. Alluvial fans and fluvial fans at the margins of continental sedimentary basins: geomorphic and sedimentological distinction for geo-energy exploration and development. Geological Society, Special Publications 440: 215-243. doi: $10.1144 /$ SP440.11.

Mosquera, A.; Ramos, V. 2006. Intraplate deformation in the Neuquen embayement. In Evolution of an Andean Margin: A Tectonic and Magmatic View From the Andes to the Neuquen en Basin ( $35^{\circ}-39^{\circ} \mathrm{S}$ lat.) (Kay, S.M.; Ramos, V.; editors). Geological Society America, Special Paper 407: 97-123.

Mpodozis, C.; Ramos, V. 1989. The Andes of Chile and Argentina. In Geology of the Andes and its relations to hydrocarbon and mineral resources (Ericksen, G.E.; Cañas, M.T.; Reinemud, J.A.; editors). CircumPacific Council for Energy and Mineral Resources, Earth Science Series: 59-89. Houston.

Muñoz, M.; Tapia, F.; Persico, M.; Benoit, M.; Charrier, R.; Farías, M.; Rojas, A. 2018. Extensional tectonics during Late Cretaceous evolution of the southern Central Andes: evidence from the Chilean main range at $\sim 35^{\circ} \mathrm{S}$. Tectonophysics 744. doi: 10.1016/j.tecto.2018.06.009.

Mutti, E. 1992. Turbidite sandstone. Instituto di Geologia Universita di Parma, Azienda Generale Italiana Petroli, Milano: 275 p. San Donato Milanese.

Nichols, G.J.; Fisher, J.A. 2007. Processes, facies and architecture of fluvial distributary system deposits. Sedimentary Geology 195 (1): 75-90.

North, C.P.; Warwick, G.L. 2007. Fluvial Fans: Myths, Misconceptions, and the End of the Terminal-Fan Model. Journal of Sedimentary Research 77 (9): 693-701.

Orts, D.L.; Folguera, A.; Giménez, M.; Ramos, V.A. 2012. Variable structural controls through time in the Southern Central Andes (ca. 36 S). Andean Geology 39 (2): 220-241. doi: 10.5027/andgeoV39n2-a02.

Ponce, J.J.; Zavala, C.; Marteau, M.; Drittanti, D. 2002. Análisis estratigráfico y modelo deposicional para la Formación Rayoso (Cretácico Inferior) en la Cuenca Neuquina, provincia del Neuquén. In Congreso Geológico Argentino, No. 15, Actas 1: 716-721. El Calafate.

Potter, P.E. 1994. Modern sands of South America: composition, provenance and global significance. Geologische Rundschau 83: 212-232. 
Ramos, V.A. 1981. Descripción geológica de la Hoja 33 c Los Chihuidos Norte, provincia del Neuquén. Servicio Geológico Nacional, Boletín 182: 1-103.

Ramos, V.A. 1999. Rasgos estructurales del territorio argentino. In Geología Argentina (Caminos, R.; editor). Instituto de Geología y Recursos Minerales, Anales 29 (24): 715-784.

Sánchez, M.; Asurmendi, E. 2016. Evolución tectoestratigráfica del relleno de sistemas de cuencas de antepaís andino cretácico: Grupo Neuquén en la región central de la Cuenca Neuquina. In Congreso Latinoamericano de Sedimentología, No. 7 y Reunión Argentina de Sedimentología, No. 15: 148 p. Santa Rosa La Pampa.

Santi Malnis, P.; Colombi, C.; Rodríguez Posatini, N.; Rothis, M.; Limarino, C.O. 2018. Caracterización sedimentológica de un Sistema Fluvial Distributivo de clima árido: arroyo Papagayos, en el piedemonte oriental de las Sierras La Huerta-Imanas, San Juan, Argentina. Andean Geology 45 (2):186-228. doi: 10.5027/andgeov45n2-3022

Scasso, R. A.; Limarino, C.O. 1997. Petrología y Diagénesis de Rocas Clásticas. Asociación Argentina de Sedimentología, Publicación Especial 1: 258 p. Buenos Aires.

Silvestro, J.; Zubiri, M. 2008. Convergencia oblicua: modelo estructural alternativo para la dorsal Neuquina $\left(39^{\circ} \mathrm{S}\right)$, Neuquén. RevistaAsociación GeológicaArgentina 63: 49-64.

Sohn, Y.Y. 1997. On traction-carpet sedimentation. Journal of Sedimentary Research 67 (3): 502-509.

Somoza, R.; Zaffarana, C.B. 2008. Mid-Cretaceous polar standstill of South America, motion of the Atlantic hotspots and the birth of the Andean cordillera. Earth and Planetary Science Letters 271: 267-277.

Sruoga, P. 2000. Descripción geológica de la hoja Volcán Maipo, Provincia de Mendoza. Informe Preliminar (Inédito), Servicio Geológico Minero Argentino. Buenos Aires.
Tassara, A.; Yáñez, G. 2003. Relación entre el espesor elástico de la litósfera y la segmentación tectónica del margen andino $\left(15^{\circ}-47^{\circ} \mathrm{S}\right)$. Revista Geológica de Chile 30 (2): 159-186. doi: 10.5027/andgeoV30n2-a02.

Tunik, M.A. 2001. Análisis sedimentológico y tectónico de la primera ingresión atlántica en la Alta Cordillera de Mendoza. Tesis doctoral (Inédito), Universidad de Buenos Aires, Facultad de Ciencias Exactas y Naturales: 257 p.

Tunik, M.; Folguera, A.; Naipauer, M.; Pimentel, M.; Ramos, V.A. 2010. Early uplift and orogenic deformation in the Neuquén Basin: Constraints on the Andean uplift from $\mathrm{U}-\mathrm{Pb}$ and $\mathrm{Hf}$ isotopic data of detrital zircons. Tectonophysics 489: 258-273.

Uliana, M.A.; Dellapé, D.A.; Pando, G.A. 1975. Distribución y génesis de las sedimentitas rayosianas (Cretácico inferior de las provincias de Neuquén y Mendoza, República Argentina). In Congreso Ibero-Americano de Geología Económica, No. 2, Tomo I: 151-176. Buenos Aires.

Vergani, G.; Tankard, A.J.; Belotti, H.J.; Welsnik, H.J. 1995. Tectonic evolution and paleogeography of the Neuquén Basin, Argentina. In Petroleum Basins of South America (Tankard,A.J.; Suárez, R.; Welsink, H.J.; editors). American Association of Petroleum Geologists Memoir 62: 383-402. doi: 10.1306/7834F6E1-1721-11D7-8645000102C1865D.

Weissmann, G.S.; Hartley, A. J.; Nichols, G.J.; Scuderi, L.A.; Olsen, M.; Buehler, H.; Banteah, R. 2010. Fluvial form in modern continental sedimentary basins: distributive fluvial systems. Geology 38:39-42.

Zavala, C.; Ponce, J.; Marteau, M. 2001. Origin, Sequence Stratigraphy and Hydrocarbon Potential of the Rayoso Formation (Aptian-Albian) in the Central Neuquén Basin (Argentina). In American Association of Petroleum Geologists Hedberg Conference "New Technologies and New Play Concepts in Latin America", Abstracts: 35-36. Mendoza.

Manuscript received: July 1, 2018; revised/accepted: September 09, 2019; available online: January 31, 2020. 